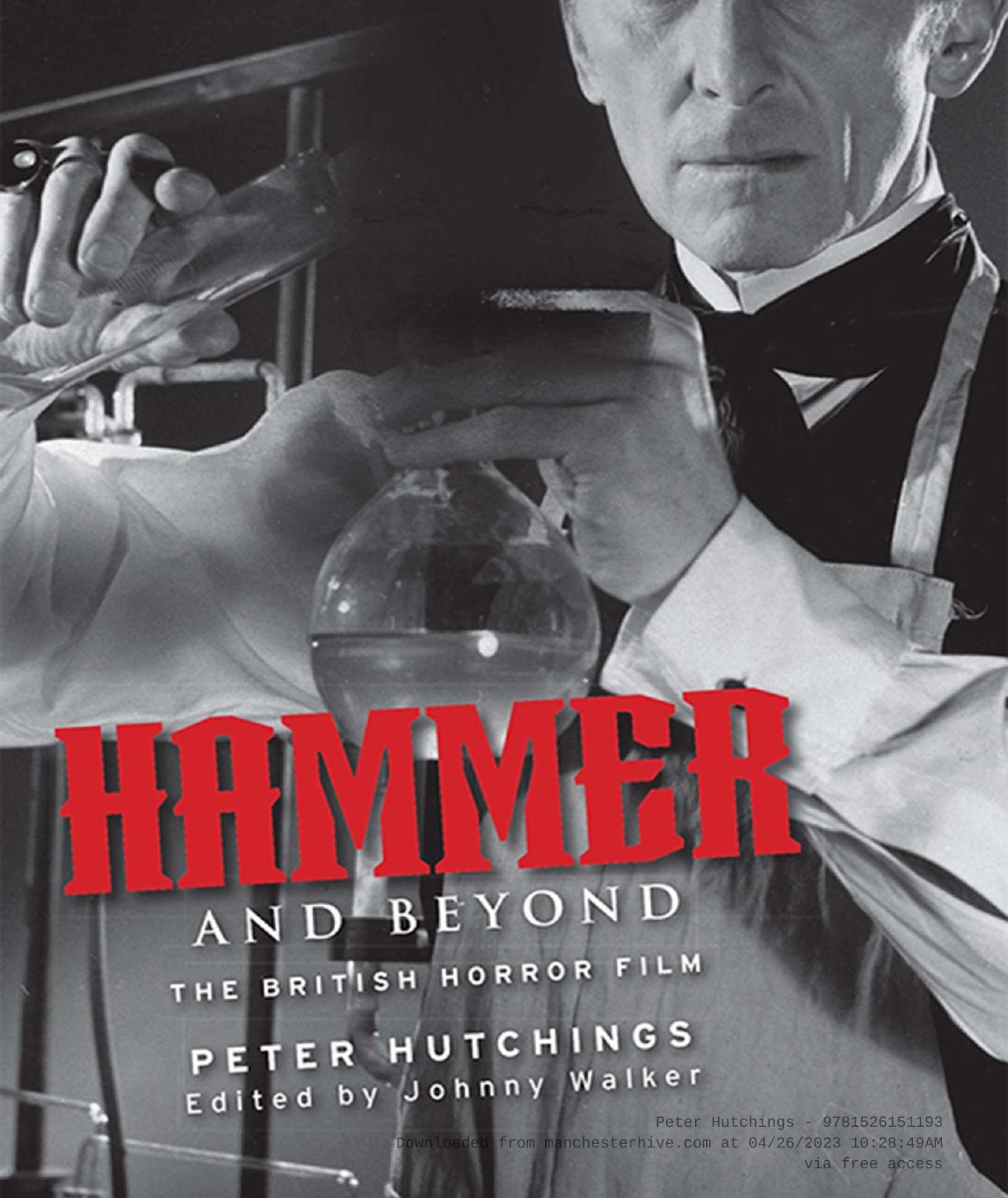




\section{Hammer and beyond}

\section{MANCHESTER 1824}

Manchester University Press 
Peter Hutchings - 9781526151193

Downloaded from manchesterhive.com at 04/26/2023 10:28:49AM 


\title{
Hammer and beyond
}

\section{The British horror film}

\author{
Peter Hutchings
}

Edited by

Johnny Walker

Manchester University Press 
Copyright $($ Estate of Peter Hutchings, 2021

Introduction to the new edition (C) Johnny Walker, 2021

Afterword @ Russ Hunter, 2021

The right of Peter Hutchings to be identified as the author of this work has been asserted by them in accordance with the Copyright, Designs and Patents Act 1988.

First edition published in 1993 by Manchester University Press

The publisher has no responsibility for the persistence or accuracy of URLs for external or any third-party internet websites referred to in this book, and does not guarantee that any content on such websites is, or will remain, accurate or appropriate.

This edition published 2021 by Manchester University Press

Altrincham Street, Manchester M1 7JA

www.manchesteruniversitypress.co.uk

British Library Cataloguing-in-Publication Data A catalogue record for this book is available from the British Library

ISBN 9781526151186 paperback

ISBN 9781526163424 hardback

This edition first published 2021

Cover credit: Peter Cushing in Frankenstein Must Be Destroyed, 1969 (photo by Evening Standard/Getty Images)

Cover design: Abbey Akanbi, Manchester University Press

Typeset by

Servis Filmsetting Ltd, Stockport, Cheshire 